\title{
The Place of X-ray Endovascular Catheter Technologies Taking into Account Errors in the Diagnostic and Treatment Algorithm of Patients with Mediastinal Tumors
}

\author{
Kravchenko Roman Yuriyovych ${ }^{1,3}$, Avdosyev Yuriy Volodymyrovych ${ }^{1,2,4}$, \\ Oleh Mykolayovych Luzan ${ }^{3}$, Yakiv Ivanovych Ivashchik ${ }^{3}$ \\ ${ }^{1}$ Department of Oncology and Pediatric Oncology of KhMAPE, Chernihiv Regional Hospital, Chernihiv, Ukraine \\ ${ }^{2}$ Medical Sciences, International Association of Endovascular Surgeons and Interventional Radiologists of Ukraine, Kharkiv, Ukraine \\ ${ }^{3}$ The Surgical Thoracic Department, Chernihiv Regional Hospital, Chernihiv, Ukraine \\ ${ }^{4}$ The X-ray Surgical Department, V. T. Zaitsev Institute of General and Urgent Surgery, Department of Surgical Anatomy and Surgery, \\ Operations V. N. Karazina, Kharkiv, Ukraine
}

Email address:

romankrava1985@ukr.net (K. R. Yuriyovych)

${ }^{*}$ Corresponding author

\section{To cite this article:}

Kravchenko Roman Yuriyovych, Avdosyev Yuriy Volodymyrovych, Oleh Mykolayovych Luzan, Yakiv Ivanovych Ivashchik. The Place of Xray Endovascular Catheter Technologies Taking into Account Errors in the Diagnostic and Treatment Algorithm of Patients with Mediastinal Tumors. American Journal of Biomedical and Life Sciences. Vol. 9, No. 5, 2021, pp. 271-278. doi: 10.11648/j.ajbls.20210905.18

Received: September 26, 2021; Accepted: October 20, 2021; Published: October 30, 2021

\begin{abstract}
The purpose of the study. Increase the effectiveness of treatment of patients with epithelial tumors of the mediastinum by using intra-arterial chemoembolization as a neoadjuvant therapy to create ischemia and high concentrations of cytostatics in tumors for a long period of time to achieve devitalization of tumor tissue and reduce overall toxicity of chemotherapy. Object of study. Epithelial tumors of the thymus gland. Research methods: Clinical, laboratory, morphological, instrumental, statistical. Laboratory tests will include general clinical blood tests, biochemical parameters (ALT, AST, bilirubin, alkaline phosphatase, gammaglutamine transpeptidase, lactate dehydrogenase, albumin), biochemical markers of thymus tumor (AFP, HGT), acetylcholine. General blood test (hemoglobin, erythrocytes, leukocytes, platelets). Instrumental methods of examination will include CT (computed tomography) with intravenous contrast, MRI (magnetic resonance imaging). The conclusions can be made from the literature review. It can be stated that there is no common view on the diagnosis and choice of treatment tactics for patients with epithelial tumors of the thymus. Histological heterogeneity of tumors of this anatomical region with the similarity of clinical manifestations and radiological symptoms requires the development of algorithms for their differential diagnosis and optimization of treatment. In addition, over the last decade in Ukraine there has been a significant increase in the number of mediastinal tumors, especially the thymus gland. Given mainly the young age of patients with this disease and the high degree of aggressiveness of the disease, the problem is transformed to the social level. It is also necessary to review the traditional approach to the treatment of this pathology, the first link of which is considered to be surgery.
\end{abstract}

Keywords: Combination Treatment, Endovascular Technologies, Risk of Metastasis, Intra-arterial Chemoembolization, Regional (Selective) Chemotherapy, Thymoma Formation - Thymoma, Superior Vena Cava Syndrome

\section{Introduction}

The term "thymoma" was first proposed to refer to all tumors of the thymus gland in 1900, Grandhomme and Scmike. Thymic neoplasms were described in 1867 by
Lantensau and Key for the first time.

Epithelial tumors of the thymus occur in the thymus and include thymomas and carcinomas of the thymus. Thymomas are the most common primary tumor in the anterior mediastinum, but are generally rare (1.5 cases / $1,000,000)$. Although thymomas can spread locally, they 
are much less invasive than thymic carcinomas. Patients with thymic carcinomas often have metastases. The 5-year survival of patients with thymoma reaches $90 \%$. At the same time, the 5-year survival rate for thymic carcinoma is approximately 55\% (NCCN Guidelines. Version 1. 2020). $[1,22]$

\subsection{Clinic}

Clinical manifestations depend on the size of the tumor, endocrine activity, the nature of growth with subsequent compression of adjacent structures. Non-invasive thymomas are mostly asymptomatic. The malignant nature of thymoma is determined by its invasiveness and metastasis, which leads to an increase in clinical manifestations and subsequent prognosis. From $10 \%$ to $40 \%$ of the team are combined with paraneoplastic syndromes. May develop such symptoms as intoxication, anemia, and pressure of the inferior vena cava (ERW syndrome), acinotic face, edema of the upper shoulder girdle, headaches, hemodynamic disturbances. [22, 31, 40, 46, 48]

\subsection{Diagnosis}

The main method of diagnosis in any oncological pathology is morphological verification. The main thing is to divide the tumor into an encapsulated or invasive form of the disease.

The main method of radiological diagnostics is multislice computed tomography (MSCT) with intravenous contrast and magnetic resonance imaging (MRI). Transthoracic puncture under MSCT control can also be used to obtain cytological material. [26-28, 34]

Among the more invasive methods can be used mediastinoscopy and parasternal mediastinotomy. [2]

Laboratory diagnosis includes pathohistological examination of the material, but considering that this method can not always establish the tumor, the most effective method is immunohistochemical examination, which allows to determine the malignant transformation of the tumor. Most thymic epithelial tumors do not require immunohistochemical examination to confirm the diagnosis, but in some cases there are questions in the differential diagnosis of microscopically similar tumors. Typical situations are the difference between thymoma $\mathrm{A}$ and other spindle cell tumors, or the difference between thymoma B1 and lymphoma.

Tumor A tumor epithelial cells are positive for keratins AE1, p63, CK20. It is often noted the expression of the marker CD20 by tumor epithelial cells. Focused expression of BCL - 2, EMA can be observed. TdT + immature lymphocytes in thymoma A are single. A small number of CD3 + T lymphocytes are also present in the tumor. CD20 + B lymphocytes are usually absent.

The expression of cytokeratins in thymoma $\mathrm{AB}$ is similar to thymoma type A. CD20 + tumor cells are observed in both $\mathrm{A}$ and $\mathrm{B}$ components.

The lymphocyte component consists of CD3 + T cells, most of which are immature $(\mathrm{TdT}+)$. B-lymphocytes are usually absent. Fibroblast-like elongated cells are positive for vimentin and EMA.

Epithelial tumor cells of thymoma type B1 are positive for CK19, antibodies AE1 / AE3 and negative for CK20, CD5, CD20. In almost all cases, the expression of epithelial cells p63 and PAX8. Immature T-lymphocytes express markers of cortical differentiation $(\mathrm{TdT}+, \mathrm{CD} 1 \mathrm{a}+, \mathrm{CD} 3+, \mathrm{CD} 4+, \mathrm{CD} 8$ + ), lymphocytes of medullary islets are mostly mature (CD3 +, TdT -, CD1a-). A few CD20 + B may be present.

Thymoma B2 has significantly more keratin-positive epithelial cells than thymoma B1. Epithelial cells are in close contact with immature T lymphocytes (TDT +), Ki67 - about 90\%. [24]

Thymoma B3 tumor cells are also positive for CK 19, CK5 / 6, CK7, p63, PAX8 and negative for CK20, TTF1, CD20, CD5, CD117. Immature TdT $+\mathrm{T}$ lymphocytes are present in more than $95 \%$ of cases. The sensitivity of CK19, TdT, CD1a to thymoma B3 was $100 \%, 93.8 \%, 87.5 \%$, the specificity of CD1a - 100\%, TdT - 95\%. In thymomas of types B2 and B3, the expression of PD - L1 is determined. $[25,44]$

Thymic cancer often has marked signs of tumor cell atypia, but in some cases thymoma B3 and thymus cancer may have similar histological features, making it difficult to make a differential diagnosis, especially in scanty biopsy material. Expression of markers CD5 and CD117, which is not characteristic of thymus, is detected in tumor cells of thymic carcinoma. In the study of X.-Y. Su et al. the specificity of the markers CD5 and CD117 for squamous cell carcinoma of the thymus was $100 \%$.

Most thymic neoplasms express neuroendocrine markers (synaptophysin, chromogranin). Expression of chromogranin is found in $70-90 \%$, synaptophysin - in $70 \%$ of tumors. [4-6, $8,17,21,47]$

One of the auxiliary diagnostic methods for invasive mediastinal tumors is fibroesophagoscopy (FES) and fibrobronchoscopy (FBS), which allows to determine the degree of invasion into the mediastinal structures, if any, and if possible to take a biopsy for cytological examination.

\subsection{TNM Classification}

A. Masaoka in 1981 proposed a classification of studies, which is still used today.

Stage I (T1N0M0) is a completely encapsulated tumor without invasion into the mediastinal tissue.

Stage II (T2N0M0) - tumor infiltration within adipose tissue.

Stage III (T3N0M0) - infiltration of the mediastinal pleura, pericardium, or adjacent organs: a. no invasion of large vessels, b. invasion of large vessels.

Stage IV: a. tumor with implantation in the pleura and pericardium (T4N0M0); b. tumor with lymphogenic metastases (T1 4N1-2M0); c. tumor with hematogenous metastases (T1-4N0-2M1). [14, 19, 32, 37, 41, 51] 


\subsection{Treatment}

Currently, the most radical method of treatment of thymic neoplasms is considered to be thymomectomy, which consists in the complete removal of the tumor together with the organ, the surrounding adipose tissue and lymph nodes of the anterior mediastinum.

Absolute contraindications to surgical treatment are the acute phase of myasthenia gravis, severe background diseases, as well as inflammatory processes in the field of future surgery. $[49,50]$

Thymomectomy is considered as a standard treatment for thymic neoplasms, especially in the initial stage, and the completeness of the resection is the most important prognostic factor. $[8,45]$

Thymomectomy can be supplemented by excision of adjacent tissues involved in the tumor process, if it is necessary and technically possible. $[15,16,35,36,38]$

Analysis of domestic and foreign literature shows that the level of 5 - and 10 - year survival after radical removal of stage I thymoma reaches $98-100 \%$ and $87-96 \%$, respectively. At the II stage 5 - and 10 - summer survival makes $75-84 \%$ and $62-73 \%$, at the III stage $-30-41 \%$ and $21-30 \%$ at the IV stage $-13-24 \%$ and $3-12 \%$.

Surgical treatment as an independent method can be used only in the first stage, rarely in the second stage thymus tumors, that is in encapsulated and minimally invasive tumors. In all other cases, patients are subject to combined, complex or conservative treatment. In combined and complex treatment, preference should be given to neoadjuvant methods, which allows to achieve regression of the tumor, reduce its volume, limit the invasion of surrounding tissues, as well as translate the inoperable process into operability. [39]

Endovascular technologies, namely regional chemotherapy, in the preoperative period, as a preparatory stage, will increase the level of ablastics and antiblastics in surgical treatment of thymus and reduce the percentage of cytostatics on the whole body, as in intravenous administration. Patients with a paraneoplastic syndrome will increase term of regression of displays of these syndromes. [3, 7, 9-11, 13, 18, $20,42,48]$

Intra-arterial administration of chemotherapeutics has certain advantages:

1) cytostatics in the arteries that supply blood to the tumor are injected directly into the affected area, which allows you to significantly increase the concentration of the drug in the tumor;

2) reduces the toxic effects of chemotherapy on the whole body;

3) longer action of drugs allows long-term contact of the cytostatic with tumor cells at all stages of the cell cycle.

Another key part of treatment is that after the introduction of the cytostatic, it is necessary to introduce special emboli (microspheres) to block the removal of the chemotherapeutic agent. [13]

The mechanism of selective chemotherapy of mediastinal tumors, namely intra-arterial chemoembolization, differs from the methods already described in the world literature.

\section{Description of the Method}

Through the femoral artery, by a minimally invasive method, a microcatheter is inserted into the aorta under the control of a special conductor and a hagiographic device. The blood supply to mediastinal tumors is taken into account, namely: a. thoracica interna, truncus brachiocephalicus at a. subclavia. The main purpose and novelty of the method is to enter the microcatheter in all arteries, the introduction of cytostatics in the most found vessels responsible for trophic tumors of the mediastinum, and if possible to embolize all vessels with microspheres, so that the concentration of chemotherapy was maximum in the tumor and did not affect the whole body. [13]

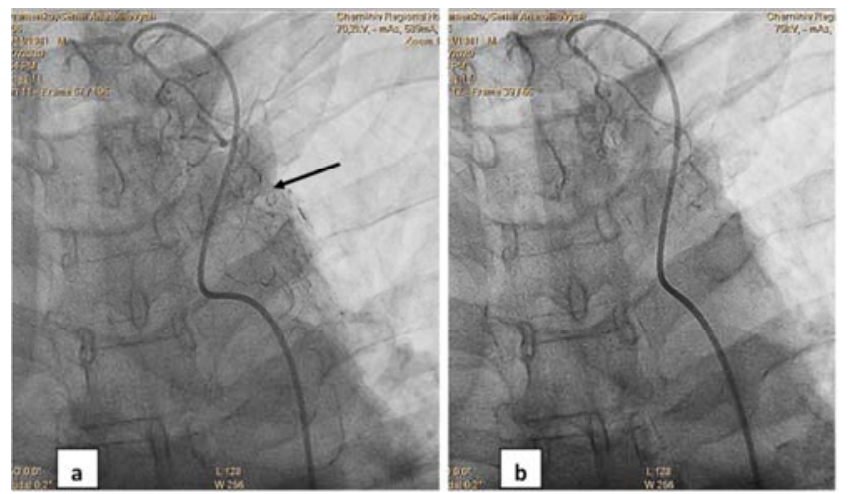

Figure 1. Angiograms of the branches of the left thyroid-cervical trunk before (a) and after (b) intra-arterial chemoembolizetion of tumor vessels of the thymus: a) contrasts the tumor formation of the thymus (arrow); b) tumor vessels do not contrast. [13]

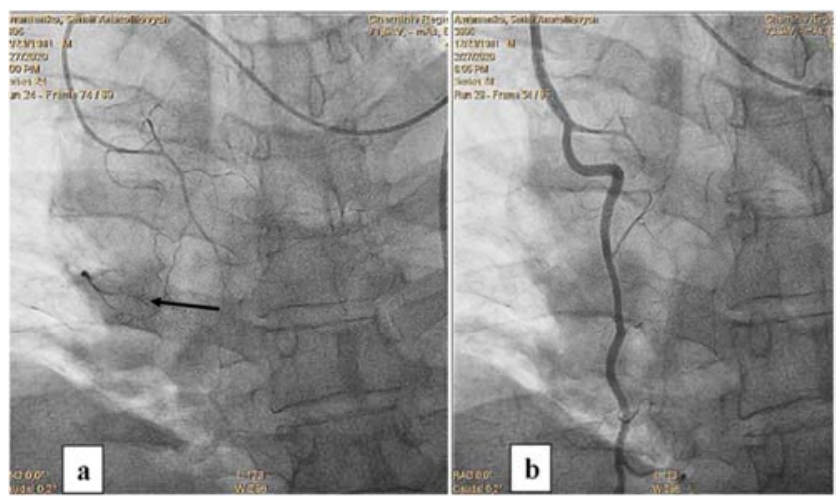

Figure 2. Angiograms of the branches of the right internal thoracic artery of the same patient before (a) and after (b) intra-arterial chemoembolizetion of tumor vessels of the thymus: a) contrasts the tumor formation of the thymus (arrow); b) tumor vessels do not contrast. [13]

Example №1. Malignant neoplasms of the mediastinum

Patient A. was born in 1981. He was admitted in March 2020 to the surgical thoracic department in serious condition.

Expressed intoxication syndrome, superior vena cava syndrome, respiratory failure of the third degree. Artopnoe.

The main diagnosis: $\mathrm{Cr}$ of the thyroid gland T3N2M0 III. II cnical group. 
Complications: Syndrome of the superior vena cava. Respiratory failure III. Artopnoe.

MSCT was performed with IV contrast: CT-signs of $\mathrm{Ca}$ thymus, intrathoracic lymphadenopathy ( $\mathrm{mts}$ ).

The patient underwent a course of intra-arterial chemoembolization with the drug Cisplatin $150 \mathrm{mg}$.

The next day, the signs of respiratory failure and superior vena cava syndrome decreased.

During treatment, the patient underwent 3 courses of intraarterial chemoembolization (Cisplatin $150 \mathrm{mg}$ ) in combination with intravenous chemotherapy (Paclitaxel 400 $\mathrm{mg})$.

After the therapy and after the control MSCT dynamics is positive.

The size of the main process has decreased by $60 \%$ since the beginning of treatment.

Example №2. Thymomas with paraneoplastic syndrome

To the patients with neurological paraneoplastic syndrome, and mostly patients with myasthenic syndrome in the acute phase, at first the dose of hormonal drugs (Medrol) and cholinesterase inhibitors (Kalimin) was selected, then conducted a course of intra-arterial chemoembolization. On the first day after intra-arterial chemoembolization there was a regression of neurological symptoms and subsequent reduction of the dose of hormonal drugs (Medrol) and cholinesterase inhibitors (Kalimin). After several courses of intra-arterial chemoembolization regression, and in some patients the complete disappearance of neurological symptoms was observed for a long time.

Patient, was born in 1967. About a year ago, the patient was first diagnosed with thymoma of the upper anterior mediastinum. Complications - myasthenia, generalized form, severe course. She was treated in the neurology department. In May 2019 she was hospitalized to the Department of Thoracic Surgery, where she underwent intra-arterial chemoembolization, a solution of Cisplatin $100 \mathrm{mg}$, mediastinal tumors.

Subsequently, the patient had an exacerbation of myasthenic syndrome. As a result, she was re-hospitalized to the thoracic surgery department, a short course of detoxification therapy was performed, and the daily dose of kalimin was increased to 6 tablets and medrol. The patient's condition stabilized.

During treatment in the thoracic department the patient conducted 3 courses of intra-arterial chemoembolization Cisplatin $100 \mathrm{mg}$.

After stabilization of the condition of myasthenia gravis and the size of the thymoma, the patient was routinely performed on 18.12.19 thymomectomy and thymectomy. In the postoperative period of myasthenic syndrome measures were carried out successfully. After that the patient developed posthypoxic encephalopathy. Brain edema. Coma I.

Pathohistological examination № 47037-44, 47045-52 dated 24.12.19). 47045-52 Lymphoepithelioid thymoma.

The main diagnosis: Lymphoepithelioid thymoma. Operation thymomectomy and thymectomy (18.12.19)
Complications of the main: Myasthenia. Generalized form, severe, pharmacoresistant. BODY (01.01.2020) Acute cardiovascular insufficiency. Asystole (01.01.2020) Posthypoxic encephalopathy. Brain edema. Coma 1. Hypostatic pneumonia. Toxic hepatitis.

Concomitant diagnosis: GC I-II st., Degree 2-3, risk 3. SN

I. Functioning tracheostomy (23.10.18)

Example №3. Errors in diagnosis and their solution.

Patient M. is 53 years old. He was admitted to the surgical torus department of the Chernihiv Regional Hospital with complaints of general weakness, moderate chest pain, and subfibril temperature.

Medical history. According to the patient and medical records, he became ill from the end of January 2021 with a body temperature to 39 degrees. At first he was treated at the local hospital for an abscess in the back of his right foot. Opening and drainage of the foot abscess was performed. During the treatment, MSCT was performed, and volume formation of the mediastinum was diagnosed. He was sent for a consultation to the Chernihiv Regional Hospital. The patient was consulted by a thoracic surgeon. He was hospitalized in the thoracic surgery department for further examination and treatment.

Life history. TBS, typhus, paratyphoid, malaria, viral hepatitis - denies. Allergic history is not burdened. There were no injuries or operations. History of type II diabetes mellitus, insulin-dependent. Not insured.

The following examinations were performed

Instrumental

1) FES Z-nnya: Compression deformation of the $c / 3$ esophagus. Moderate DGR. Erythematous gastropathy. Ulcer in the prepyloric part of the stomach, acute phase. Erythematous duodenopathy. Dyskinesia of the duodenum.

2) MSCT was performed with intravenous contrast (Ultravist-370,100ml.). fracture of Th3 vertebrae. CT signs of single small focal changes of the lungs, hydropericardium, left pleural calcification, hepatosplenomegaly, fatty hepatosis, sinus cyst of the right kidney, abnormalities in the number of renal vessels in the form of an additional renal artery on the left. Given the anamnesis, it is impossible to exclude the presence of pathological fractures of the $7^{\text {th }}$ and $8^{\text {th }}$ ribs on the right in secondary lesions.

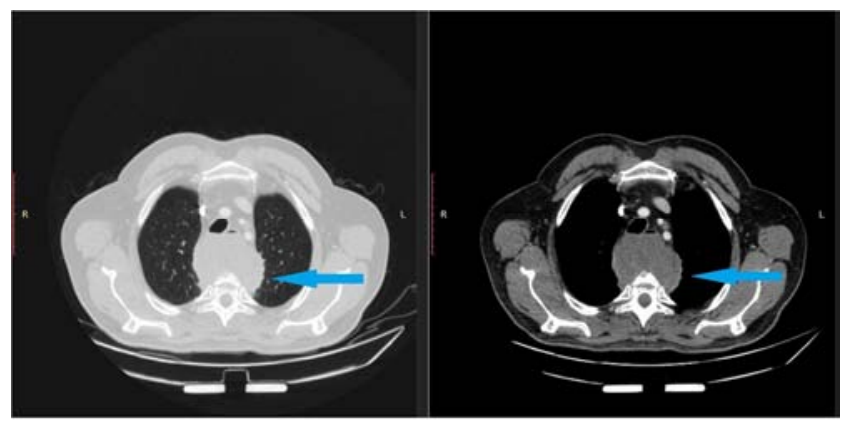

Figure 3. MSCT before surgery. 


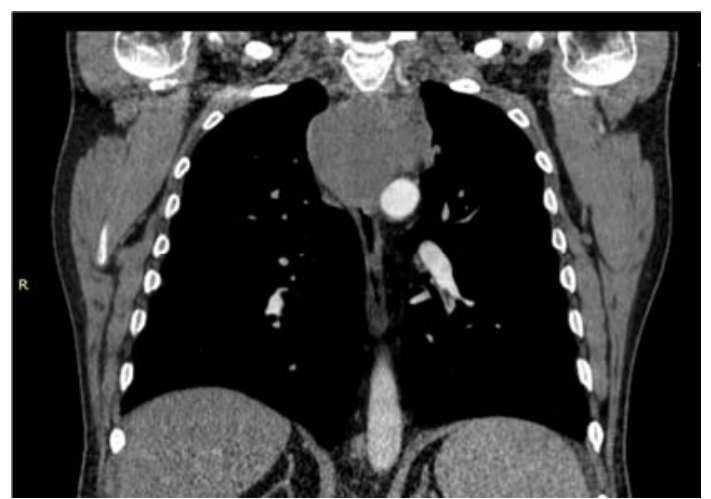

Figure 4. MSCT before surgery frontal.

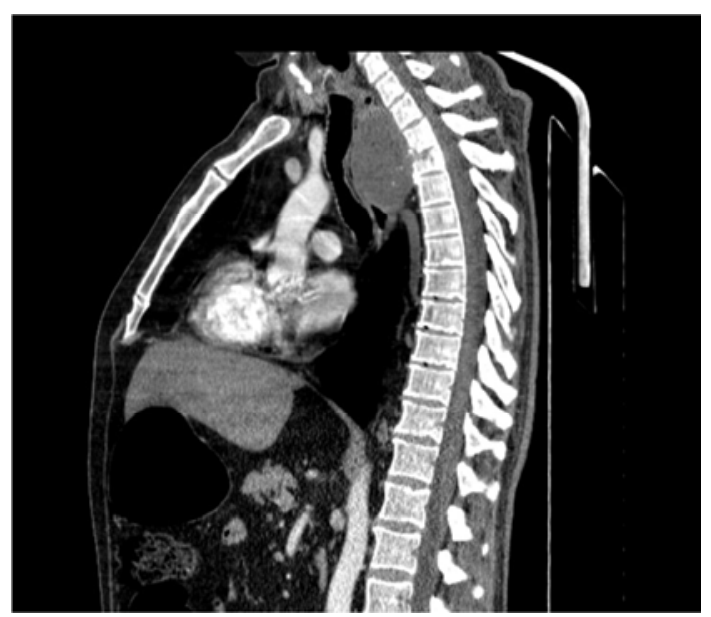

Figure 5. MSCT before surgery sagittal projection.

3) Doppler echocardiography C-tion: Aorthosclerosis. Degenerative changes of AK sash. Moderate dilatation of the LP. LVL IBE hypertrophy in the basal department. Diastolic LV dysfunction by type of relaxation disorder. The contractile function of the left ventricular myocardium is preserved, but there is a relative hypokinesis of the anterior wall of the left ventricle.

Performed before the opening of the foot abscess.

At normal indicators of red blood moderate leukocytosis, the raised ESR to $70 \mathrm{~mm} / \mathrm{h}$ was noted. Hyperglycemia to 30 $\mathrm{mmol} / \mathrm{l}$, acetone in urine +++ .

After detoxification, analgesic, antibacterial, correction of insulin therapy, the patient went from decompensated to subcompensated, but the intensity of pain in the thoracic spine increased. The patient was preparing for regional, intraarterial chemoembolization followed by systemic chemotherapy.

The surgical council decided to perform a diagnostic video thoracoscopy to take material to verify the diagnosis.

\section{Diagnosis Before Surgery}

Neoplasm of the posterior mediastinum.

The patient was taken to the operating room. The operation was performed - video-assisted thoracoscopy on the right. Opening and drainage of abscess of the middle and posterior mediastinum. Biopsy.
After the operation, the patient's condition improved. Glycemic parameters returned to normal.

X-ray after the surgery. Conclusion: Shadow of functioning drainages. Condition after surgery. Compared with the image before the operation, the dynamics is positive due to the reduction of the area of shading, which is projected in the lower lobe of the right lung. The pulmonary drawing on the right is strengthened at the expense of a vascular component. The roots of the lungs are not structural. Sinuses - the case is visualized. Left out of the frame. The shadow of the upper mediastinum is expanded. Heart is expanded due to the left divisions.

Fibroesophagoscopy after the surgery. Conclusion: The esophagus is passabled. The mucosa is diffusely hyperemic, swollen. Compression, previously described, is absent. Reflux esophagitis C (LA) Peptic ulcer of the esophageal cardia (Savary). Signs of sliding hernia of the esophageal orifice of the diaphragm. Erosive gastropathy. Ulcer of the antrum of the stomach subacute phase. Congestive duodenopathy.

Bacterioscopic examination of the contents of the abscess of the middle and posterior mediastinum of the MBT negative.

MSCT with IV contrast after the surgery. Conlusion: In comparison with the data of MSCT examination from previous examinations there is a decrease in the size of the main process in the posterior mediastinum, but an increase in the degree of destruction of Th3 vertebrae and its height in the anterior and central divisions fluid in the right pleural cavity, increasing the size of intrathoracic lymph nodes and the degree of accumulation of contrast agent, increasing the size of the focus in S10 of the right lung, reducing the amount of fluid in the pericardial cavity.

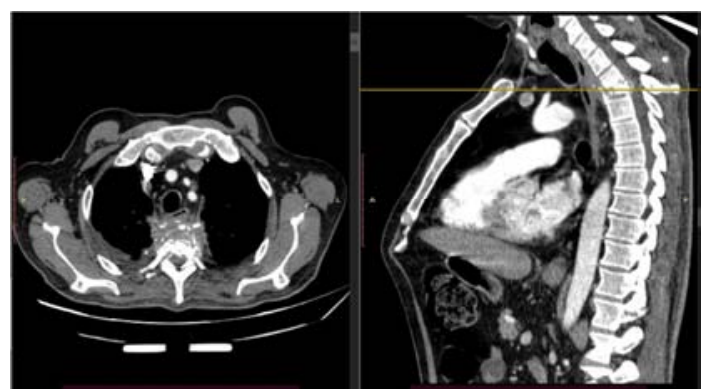

Figure 6. MSCT after surgery.

\section{Pathohistological Examination}

1) In the sent material fragments of connective, fatty and muscular tissues with chronic nonspecific inflammatory process, areas of purulent inflammation with necrosis, development of granulation tissue, focal sclerosis, hyalinosis. 2) In the sent material connective tissue with chronic nonspecific inflammatory process, severe sclerosis, hyalinosis, focal accumulations of xanthoma cells, areas of purulent inflammation with necrosis and the development of granulation tissue.

A medical consultation was convened to formulate a diagnosis and further recommendations. 
The main diagnosis: Type 2 diabetes- is insulin dependent, severe, decompensated condition.

The main complication: Diabetic microangiopathy of the vessels of the lower extremities. Osteoarthropathy. Diabetic neuropathy. Diabetic foot on the right, mixed form. Granulating wound of the back of the foot after opening the abscess. Septic condition. Abscess of the middle and posterior mediastinum. Spondylitis with destruction of Th2 Th3 vertebrae. Reactive erosive-ulcerative esophagitis. Intoxication.

Concomitant diagnosis: Gastric ulcer.

The patient was discharged with improvement. Recommendations were given.

Evidence of surgical treatment of benign thymus tumors for 2018-2021 $(\mathrm{n}=9)$ :

1) With myasthenia - 5 patients;

2) No symptoms - 4 patients.

Thoracotomy (thymomectomy, thymectomy) - 5 patients

X-ray endovascular surgery - 3 patients

Conservative therapy - 1 patient

One month after treatment, 7 patients had no symptoms.

One patient had complications in the form of recurrences of myasthenia gravis and cerebral edema, which required tracheotomy and resuscitation.

Evidence of surgical treatment of thymic malignancies for 2018-2020 (n=6):

With superior vena cava syndrome - 4 patients.

Thoracotomy - 1 patient

Videothoracoscopy - 1 patient

Operation + intra-arterial administration of chemotherapy 1 patient

Radiation therapy + intra-arterial administration of cytostatics - 1 patient

Conservative therapy - 2 patients

Died in the early postoperative period - 2 patients

Died of concomitant complications (cerebral edema, acute cardiovascular failure) without surgery - 1 patient.

A total of $3(20.0 \%)$ patients died.

\section{Conclusion}

Tumors of the mediastinum are a rare pathology, the difficulty of detection of which is due to the lack of specific symptoms and the possibility of long-term asymptomatic course. Surgical treatment plays an important role in the treatment and proper diagnosis of interstitial tumors, especially malignant. The use of minimally invasive diagnostic methods (videothoracoscopy, transthoracic needle biopsy) allows to obtain morphological verification in preparation for treatment and to choose the safest and optimal type of treatment for patients with this pathology. But, as the second example shows, radical surgery may not always be basic and generally used as a treatment. For 3 years we treated about 300 patients with specific and nonspecific diseases of different localizations by the method of intra-arterial chemoembolization. Thanks to X-ray endovascular technologies, we transferred lung cancer from non-resection to the possibility of surgery, stabilization of the main process or metastatic foci or reduction in their size. In patients with thymoma with paraneoplastic syndrome after 23 courses of intra-arterial chemoembolization there was a complete or prolonged regression of manifestations of myasthenia. Patients with malignant (invasive) thymomas, who had pronounced manifestations of the syndrome of the superior vena cava, respiratory failure, after the $1^{\text {st }}$ course of this therapy experienced improvement on the $1^{\text {st }}, 2^{\text {nd }}$ day.

X-ray endovascular methods of treatment should be in the algorithm of each pathology, any localization of the process.

\section{References}

[1] NCCN Guidelines. Version 1.2020. Thymomas and Thymic Carcinomas.

[2] Ганул А. В. Оптимизация диагностики и лечения пациентов со злокачественными опухолями средостения. Онкология. [Optimization of diagnosis and treatmet of patients with malignant mediastinal tumors. Oncology.] - 2009, т. 11, №2- C. 131-135.

[3] Борисюк Б. О. Внутриартериальная регионарная полихимиотерапия при комплексном лечении злокачественных новообразований средостения. Онкология. [Intra-arterial regional polychemotherapy in the complex treatment of malignant neoplasms of the mediastinum. Oncology]. - 2009, т. 11, №2- C. 136-138.

[4] Александров О. А. Тимома (обзор литературы) [Timoma (literature review)] / О. А. Александров, А. Б. Рябов, О. В. Пикин // Сибирский онкологический журнал. [Siberian Journal of Oncology.] - 2017. - T. 16. -№4. - C. 76-83.

[5] Александров О. А. Трансторакальная толстоигольная биопсия опухолей средостения под контролем ультразвуковой навигации [Transthoracic thickneedle biopsy of mediastinal tumors under the control of ultrasound navigation.] / О. А. Александров, С. О. Степанов, О. В. Пикин, Н. Н. Волченко, В. Соловьев, П. Д. Беспалов, Д. А. Вурсол // Онкология. Журнал им. П. А. Герцена. [Oncology. Journal by P. A. Herzen.] - 2019. - Том 8, №2. C. 88-93.

[6] Алексеева Т. М. Клинико-иммунологические особенности миастении и подходы к ее терапии у лиц пожилого возраста (обзор литературы)[Clinical and immunological features of myasthenia gravis and approaches to its therapy in the ederly (literature review)] / Т. М. Алексеева, В. Д. Косачев, А. Н. Халмурзина // Нервно-мышечные болезни. [Neuromuscular diseases]- 2016. - T. 6.- №3. - C. 10-16.

[7] Интервенционная радиология в онкологии (пути развития и технологии): научно-практическое издание [Interventional radiology in oncology (ways of development and technologies): scientific and practical edition]/ гл. ред.: А М. Гранов, М. И. Давыдов; ред.: П. Г. Таразов, Д. А. Гранов, Б. И. Долгушин, В. Н. Полысалов, А. А. Поликарпов. $-2007 .-344$ с.

[8] Борисова Т. Н. Клинические рекомендации по диагностике и лечению больных опухолями средостения и вилочковой железы/[Clinical guidelines for the diagnosis and treatment of patients with tumors of the mediastinum and thymus] Т. Н. Борисова, В. В. Бредер, В. А. Горбунова, С. М. Иванов.- 2014.- с. 64. 
[9] Кудрявцев А. С. Робот-ассистированные вмешательства в торакальной хирургии (первый опыт) [Robot-assisted interventions in thoracic surgery (the first experience)]/ A. C. Кудрявцев, С. В. Ярмощук, Е. А. Дробзягин, А. Н. Архипов // Сибирский Научный Медицинский Журнал. [Siberian Scientific Medical Journal]- T. 35.- № 6.- 2015.- C. 56-59.

[10] Руководство по химиотерапии опухолевых заболеваний. Издание 4-e [Guidelines for the chemotherapy of neoplastic diseases. The $4^{\text {th }}$ edition.] Переводчикова Н. И., Горбунова В. А. (под ред.) Изд. «Практическая медицина» [(edited by) Publ. Practical Medicine], 2015. —688 c.

[11] Курганов И. А. Роль и место малоинвазивных хирургических технологий в лечении заболеваний вилочковой железы The role and place of minimally invasive surgical technologies in the treatment of diseases of the thymus gland/ И. А. Курганов, Д. Ю. Богданов // Эндоскопическая хирургия. Endoscopic surgery- 2013. -№6. - C. 49-54.

[12] Сигал Е. И. Результаты видеоторакоскопической тимэктомии у пациентов с миастенией в сочетании с опухолевой патологией вилочковой железы [Results of videothoracoscopic thymectomy in patients with tumor pathology of the thymus gland]/ Е. И. Сигал, Р. Е. Сигал, А. M. Сигал, М. В. Бурмистров // Поволжский онкологический вестник. [Povolzhsky Oncological Journal] - 2015. - №2. - C. 11-17.

[13] Ю.В.Авдосьєв, І. В. Белозьоров/ Інтервенційна радіологія в онкології [Interventional radiology in oncology]- 2020.- P. 170-174.

[14] Achey, R. L. Rare thymoma metastases to the spine: case reports and review of the literature // R. L. Achey, B. S. Lee, S. Sundar, E. C. et al. // World Neurosurg. - 2018. - Vol. 110. P. 423-431.

[15] Bleetman D. Video-assisted thoracoscopic thymectomy / D. Bleetman, D. West, E. Teh, E. Internullo // Annals of Cardiothoracic Surgery. - 2015. - Vol. 4.-№ 6. - P. 556-557.

[16] Cheng Y. J. Videothoracoscopic resection of stage II thymoma: prospective comparison of the results between thoracoscopy and open methods/Y. J. Cheng, E. L. Kao, S. H. Chou// Chest.- 2015.-№128.-P. 3010-3012.

[17] Den Bakker M. A. Histologic classification of thymoma: a practical guide for routine cases / M. A. den Bakker, A. C. Roden, A. Marx, M. Marino // J. Thorac. Oncol. - 2014. - Vol. 9. - P. 125-S130.

[18] Detterbeck F. C. Thymoma: current diagnosis and treatment / F. C. Detterbeck, A. Zeeshan // Chin. Med. J. - 2013. - Vol. 126, №11.- P. 2186-2191.

[19] Fukui T. Middle mediastinal thymoma / T. Fukui, R. Sumitomo, Y. Otake, C. L. Huang // Ann. Thorac. Surg. 2018. - Vol. 106, №4. - P. 189-191.

[20] Fukushima T. Successful salvage chemotherapy with amrubicin for invasive thymoma associated with myasthenia gravis / T. Fukushima, D. Gomi, T. Kobayashi, N. Sekiguchi, A. Sakamoto, S. Sasaki, T. Koizumi // Japanese Journal of Clinical Oncology. - 2014. - Vol.-44, N. 11. - P. 1120-1122.

[21] Gentili F. Update in diagnostic imaging of the thymus and anterior mediastinal masses / F. Gentili, V. Pelini, G. Lucii et al. // Gland Surg. - 2019. - Vol. 8 (Suppl. 3). - P. 188-S207.

[22] Girard N. Thymic epithelial tumours: ESMO clinical practice guidelines for diagnosis, treatment and follow-up / N. Girard, E. Ruffini, A. Marx, C. Faivre-Finn, S. Peters // Annals of Oncology. - 2015. - Vol. - 26, N. 5. - P. 40-55.

[23] Goldstein A. J. A tour of the thymus: a review of thymic lesions with radiologic and pathologic correlation / A. J. Goldstein, I. Oliva, H. Honarpishen, A. Rubinowitz // Canadian Association of Radiologist Journal. - 2015. - Vol. 66, Issue1. - P. 5-15

[24] Gong L. World Health Organization type B2 thymoma with an abundance of Hassall s corpuscles: a case report / L. Gong, L. Sun, C. Zhang et al. // Oncol. Lett. - 2018. Vol. 15, №6. P. 9283-9286.

[25] Guleria P. PD-L1 immuno-expression assay in thymomas: Study of 84 cases and review of literature / N. Husain, S. Shukla, S. Kumar et al. // Ann. Diagn. Pathol. - 2018. - Vol. 34. - P. 135-141.

[26] Hakiri S. Clinicopathologic features of thymoma with the expression of programmed death ligand 1 / S. Hakiri, T. Fukui, S. Mori et al. // Ann. Thorac. Surg. - 2019. - Vol. 107, №2. P. 418-424.

[27] Hamaji M. A meta-analysis of debulking surgery versus surgical biopsy for unresectable thymoma / M. Hamaji, F. Kojima, M. Omasa, T. Sozub // European Journal of CardioThoracic Surgery. - 2015. - Vol. 47. - P. 602-607.

[28] Hess N. R. Minimally invasive versus open thymectomy: a systematic review of surgical techniques, patient demographics, and perioperative outcomes / N. R. Hess, I. Sarkaria, A. Pennathur, R. M. Levy //Annals of Cardiothoracic Surgery. - 2016. - Vol. 5.-№1. - P. 1-9.

[29] Huang J. A new staging system for thymoma-will it improve outcomes? / J. Huang // The Journal of Thoracic and Cardiovascular Surgery. - 2015. - Vol. 51.-№ 1. - P. 20-22.

[30] Huang P. Solitary metastasis to the breast after complete resection of encapsulated type $\mathrm{AB}$ thymoma: a case report / $\mathrm{P}$. W. Huang, K. M. Chang // Journal of Medical Case Reports. 2015. - Vol. - 9. - P. 1-5

[31] Jamilloux Y. Thymoma and autoimmune disease / Y. Jamilloux, H. Frih, C. Bernard et al. / Rev. Med. Interne. 2018. - Vol. 39, №1. - P. 17-26.

[32] Kaba E. Role of surgery in the treatment of Masaoka stage IVa thymoma / E. Kaba, B. Ozkan, S. Erus, S. Duman // Annals of Thoracic and Cardiovascular Surgery. - 2017. - Vol. 24.-№1. - P. 6-12.

[33] Leuzzi G. Multimodality therapy for locally advanced thymomas: A propensity score-matched cohort study from the European Society of Thoracic Surgeons Database / G. Leuzzi, G. Rocco, E. Ruffini, I. Sperduti, F. Detterbeck, W. Weder, F. Venuta, D. V. Raemdonck, P. Thomas, F. Facciolo // The Journal of Thoracic and Cardiovascular Surgery. - 2015. - Vol. - 151, N. 1. - P. 47-57.

[34] Li X. Preoperative misdiagnosis analysis and accurate distinguish intrathymic cyst from small thymoma on computed tomography / X. Li, X. Han, W. Sun, M. Wang, G. Jing, X. Zhang// Journal of Thoracic Disease. - 2016. - Vol. 8, N. 8. - P. 2086-2092. 
[35] Liu Z. Unilateral video-assisted thoracoscopic extended thymectomy offers long-term outcomes equivalent to that of the bilateral approach in the treatment of non-thymomatous myasthenia gravis/ Z. Liu, J. Yang, L. Lin// Interact. Cardiovasc. Thorac. Surg.- 2015.-№21.- P. 610-615.

[36] Lushina N. Outpatient video-assisted thoracoscopic thymectomy in an octogenarian / N. Lushina, C. F. Hynes, M. B. Marshall // Journal of Visualized Surgery. - 2016. - Vol. 2.№ 168. - P. 1-3.

[37] Marx A. The 2015 World Health Organization classification of tumors of the thymus / A. Marx, J. K. C. Chan, J. M. Coindre, F. Detterbeck // Journal of Thoracic Oncology. - 2015. - Vol. 10.-№10. - P. 1383-1395.

[38] Matilla J. R. Thymic minimally invasive surgery: state of the art across the world-Europe / J. R. Matilla, W. Klepetko, B. Moser // Journal of Visualized Surgery. - 2017. - Vol. 3.-№. 70. - P. 1-6.

[39] Melfi F. M. Minimally invasive mediastinal surgery// Melfi F. M., Fanucchi O., Mussi A. // Ann. Cardiothoracic Surg. 2016. - Vol 5.-№1.-P. 10-17.

[40] Park N. O. Ectopic cervical thymoma: a case report and review / N. O. Park, S. H. Kim, S. H. Moon et al. // Korean J. Thorac. Cardivasc. Surg. - 2017. - Vol. 50, №4. - P. 312-315.

[41] Scorsetti M. Thymoma and thymic carcinoma / M. Scorsetti, F. Leo, A. Trama, et al. // Critical Reviews in Oncology/Hematology. - 2016. - Vol. 99. - P. 332-350.

[42] Shen J. Jnter-relationship among myasthenia gravis, WHO histology, and Masaoka clinical stage and effect on surgical methods in patients with thymoma: a retrospective cohort study / J. Shen, H. Tie, A. Xu et al. // J. Thorac. Dis. - 2018. Vol. 10, №5. - P. 2981-2990.

[43] Speisky D. Hepatic metastasis of thymoma: case report and immunohistochemical study / D. Speisky, M. T. G. de Davila, F. Vigovich, J. Mendez, R. Maurette, M. G. Ejarque, J. C.
Spina, A. Iotti, P. Dezanzo // Ecancer. - 2016. - Vol. 10. N. 693. - P. 1-6.

[44] Su X.-Y. Immunohistochemical differentiation between type B3 thymomas and thymic squamous cell carcinomas / X.-Y. Su, W.-Y. Wang, J.-N. Li.// Int. J. Clin. Exp. Pathol. - 2015. Vol. 8, №5. - P. 5354-5362.

[45] Tassi V. Could thymomectomy be a reasonable option for nonmyasthenic thymoma patients? / V. Tassi, S. Ceccarelli, C. Zannori, A. Gili, N. Daddi, G. Bellezza, S. Ascani, A. M. Liberati, F. Puma // Journal of Thoracic Disease. - 2017. - Vol. 9, N. 10. - P. 3817-3824.

[46] Uchio N. Inflammatory myopathy with myasthenia gravis: thymoma association and polymyositis pathology / N. Uchio, K. Taira, C. Ikenaga et al. // Neurol. Neuroimmunol. Neuroinflamm. - 2018. - Vol. 6, №2. - P. 535.

[47] $\mathrm{Wu} \mathrm{J}$. The enlightenments from ITMIG Consensus on WHO histological classification of thymoma and thymic carcinoma: refined definitions, histological criteria, and reporting / J. Wu, W. Fang, G. Chen // J. Thorac. Dis. - 2016. - Vol. 8, №4. - P. 738-743.

[48] Dinkel H. P. Endovascular treatment of malignant superior vena cava syndrome: is bilateral Wallstent placement superior to unilateral placement? / H. P. Dinkel, B. Mettke, F. Schmid et al. // J. Endovasc. Ther. - 2003. - Vol. 10. - P. 788-797.

[49] Jaretzki A. Thymectomy for myasthenia gravis: analysis of controversies patient management / A. Jaretzki // Neurologist. - 2003. - Vol. 9. -P. 77-92.

[50] Mack M. J. Video-assisted thoracoscopy thymectomy for myasthenia gravis II / M. J. Mack // Chest Surg. Clin. N. Am. 2001. - Vol. 11, № 2. - P. 389-406.

[51] Masaoka A. Extended transsternal thymectomy for myasthenia gravis / A. Masaoka // Chest Surg. Clin. N. Am. - 2001. - №2. - P. 369-387. 